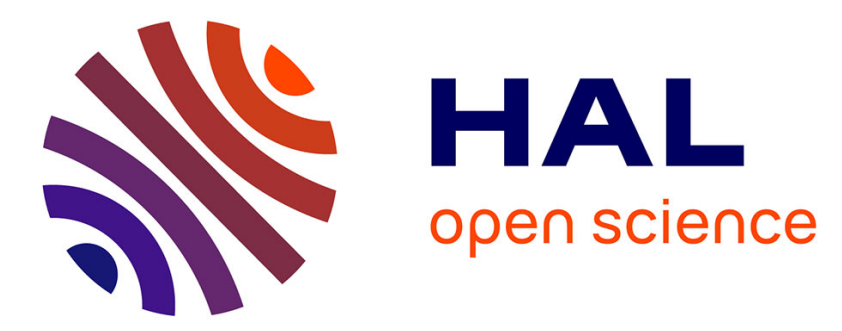

\title{
Hemodialysis patients with diabetes eat less than those without: a plea for a permissive diet
}

Stanislas Bataille, Jean Landrier, Julien Astier, Sylvie Cado, Jérôme Sallette, Philippe Giaime, Jérôme Sampol, Hélène Sichez, Jacques Ollier, Jean Gugliotta, et al.

\section{To cite this version:}

Stanislas Bataille, Jean Landrier, Julien Astier, Sylvie Cado, Jérôme Sallette, et al.. Hemodialysis patients with diabetes eat less than those without: a plea for a permissive diet. Nephrology, 2016, 22 (9), 10.1111/nep.12837 . hal-01478314

\section{HAL Id: hal-01478314 https://hal.science/hal-01478314}

Submitted on 26 Sep 2017

HAL is a multi-disciplinary open access archive for the deposit and dissemination of scientific research documents, whether they are published or not. The documents may come from teaching and research institutions in France or abroad, or from public or private research centers.
L'archive ouverte pluridisciplinaire HAL, est destinée au dépôt et à la diffusion de documents scientifiques de niveau recherche, publiés ou non, émanant des établissements d'enseignement et de recherche français ou étrangers, des laboratoires publics ou privés. 


\section{Original article}

\section{Hemodialysis patients with diabetes eat less than those without:}

\section{a plea for a permissive diet.}

\section{Short title: Dietary intake in hemodialysis diabetic patients}

Stanislas Bataille, $\mathrm{MD}^{1,2,3}$; Jean-François Landrier, $\mathrm{PhD}^{4,5,6}$; Julien Astier, $\mathrm{PhD}^{4,5,6}$; Sylvie Cado, $\mathrm{PhD}^{7}$; Jérôme Sallette, $\mathrm{PhD}^{8}$; Philippe Giaime, $\mathrm{MD}^{1,2}$; Jérôme Sampol, $\mathrm{MD}^{1,2}$; Hélène Sichez, $\mathrm{MD}^{1,2}$; Jacques Ollier, MD ${ }^{1,2}$; Jean Gugliotta, $\mathrm{MD}^{1,2}$; Marianne Serveaux, $\mathrm{MD}^{1,2}$; Julien Cohen ${ }^{9}$ and Patrice Darmon, $\mathrm{MD} \mathrm{PhD}^{4,5,6}$.

${ }^{1}$ Phocean Nephrology Institute, Marseille, France

${ }^{2}$ Centre de Néphrologie, Clinique Bouchard, Marseille, France

${ }^{3}$ Nephrology Dialysis Renal Transplantation Center, APHM, CHU Conception, Marseille, France

${ }^{4}$ Institut National de Recherche Agronomique, Unité Mixte de Recherche 1260, France

${ }^{5}$ Inserm, Unité Mixte de Recherche 1062, Nutrition, Obésité et Risque Thrombotique, France ${ }^{6}$ Faculté de Médecine, Aix-Marseille Université, F-13385 Marseille Cedex 05, France

${ }^{7}$ Laboratoire Cerba, Saint-Ouen l'Aumône, France

${ }^{8}$ Cerba Healthcare, Saint-Ouen l'Aumône, France

${ }^{9}$ Medistats, Marseille, France

Corresponding author: Dr Stanislas Bataille, MD, Phocean Nephrology Institute Clinique Bouchard, 77 rue du Docteur Escat, 13006 Marseille, France, Tel: +33 (0)4 911590 85, Fax: +33 (0)491 1590 60, Email: $\underline{\text { stanislas.bataille@ @ap-hm.fr }}$

This article has been accepted for publication and undergone full peer review but has not been through the copyediting, typesetting, pagination and proofreading process which may lead to differences between this version and the Version of Record. Please cite this article as doi: 10.1002/NEP.12837 


\section{$\underline{\text { Abstract }}$}

\section{Aim}

The main cause of malnutrition in hemodialysis patients is a spontaneous decline in energy and protein intakes. This study aims to report the dietary energy intake (DEI), dietary protein intake (DPI), and dietary micronutrient intake in a French HD population, to report factors associated with a low DPI and DEI, and to analyze if nutritional intake was correlated with nutritional status.

\section{Methods}

We conducted an observational cross-sectional study in a hemodialysis population of 87 adult patients in July 2014. Daily nutritional oral intake, handgrip strength, body composition measured by bioimpedancemetry, and biological and dialysis parameters were obtained from medical records. Statistical analyses of parameters associated with DEI and DPI were performed.

\section{Results}

The median age (interquartile range) of the population was $77.3[71.1 ; 84.8]$ years, $57.5 \%$ were men, and $52.9 \%$ had diabetes mellitus. Median weight-adjusted DEI was $18,4[15.7 ; 22.3] \mathrm{kcal} / \mathrm{kg} /$ day $(1308[1078 ; 1569] \mathrm{kcal} / \mathrm{day})$, and median weight-adjusted DPI was $0.80[0.66 ; 0.96] \mathrm{g} / \mathrm{kg} /$ day $(57.5[47.1 ; 66.8] \mathrm{g} /$ day $)$.

In multivariate analysis, weight-adjusted DEI was statistically lower in patients with diabetes (coefficient $[95 \% \mathrm{CI}]-3.81[-5.21 ;-2.41] \mathrm{kcal} / \mathrm{kg} / \mathrm{day} ; p=0.01$ ) but was not associated with the others parameters. When DEI was not adjusted for weight, diabetes was no longer associated with DEI, but female gender $(-178[-259 ;-961] \mathrm{kcal} /$ day; $p=0.03)$ and a higher Charlson comorbidity index $(-30[-44 ;-15] ; \mathrm{p}=0.04)$ were associated with a lower calorie intake. Results for DPI were similar except that the Charlson comorbidity index did not reach significance. 


\section{Conclusions}

Diabetes is an important factor associated with low dietary intake in hemodialysis patients.

Restrictive regimens should be prescribed cautiously in hemodialysis patients, especially in those with diabetes.

Keywords: diabetes, dietary intake, hemodialysis, nutritional intake, protein energy wasting syndrome.

\section{Conflict of interest}

None to be declared.

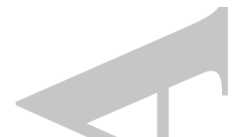

\section{Introduction}

Malnutrition is a major complication of chronic renal failure, occurring in $1 / 4$ to $1 / 3$ of hemodialysis (HD) patients according to malnutrition diagnosis criteria [1, 2]. In patients with chronic renal failure, malnutrition has been included within the well-named ProteinEnergy Wasting syndrome (PEW). PEW is a state where decreased body stores of protein and energy fuels are caused by low nutrient intake, but also from hyper-catabolism or protein loss during HD or peritoneal dialysis [3, 4]. Large epidemiologic studies reveal a strong correlation between PEW and mortality in end-stage renal disease (ESRD) [5].

European Best Practices Guidelines on nutrition recommend that maintenance HD patients consume at least $1.1 \mathrm{~g} / \mathrm{kg} /$ day dietary protein intake (DPI) and have a dietary energy intake (DEI) of 30-40 kcal/kg/day [1], but restrictive regimens -with low phosphate, potassium or sodium intakes- are also recommended [1]. Dietary intake studies in ESRD populations have recently been reviewed [6]. Most studies report insufficient DPI and DEI in patients with chronic renal failure, and even lower intakes in HD patients. Low DPI and DEI have been linked to increased morbidity and mortality $[5,7,8]$. 
Unfortunately, most studies on DEI and DPI in HD populations have been performed outside of Europe, and very few in France, where populations might have significantly different diets based on population nutritional habits [9]. Moreover, many studies have taken place before the year 2000, and HD population characteristics have changed since then. For example, mean age of hemodialysis populations is increasing in most countries [10]. Finally, in most studies, no analyses of factors leading to a poor nutritional intake have been performed, and no correlations made between low intakes and nutritional status [6].

The aim of this study was to report DPI, DEI, and dietary micronutrient intakes in a recent HD French population, to report factors associated with a low DPI and DEI, and to analyze if nutritional intake was correlated with nutritional status.

\section{Materials and Methods}

We conducted an observational cross-sectional study on all patients from our HD center in July 2014. All patients with data available regarding nutrition were included, except for pregnant women or patients aged $<18$ years. Patients unable to report a reliable nutritional intake diary were excluded. Written information was provided to all patients, and all gave consent for their personal data to be used for research purposes. According to French law, it is neither necessary nor possible to obtain approval from an ethical committee (in French CPP, Comité de Protection des Personnes) for this type of non-interventional study. Moreover, CPPs are not entitled to issue waivers of approval for this type of study. Nevertheless, this study obtained approval from the Health Research Data Processing Advisory Committee (in French CCTIRS, Comité consultatif sur le traitement de l'information en matière de recherche dans le domaine de la santé). 
Data on all patients who performed the handgrip strength test as well as detailed methodology have been published elsewhere; however the present study included the patients who could not perform the handgrip test, but not those where DPI and DEI were not recorded [11]. Briefly, clinical and biological data, body composition measured using bioimpedancemetry analyses (BIA), and 48-hour nutritional intake assessments by dieticians were recorded.

The following data were collected from the patients' medical files: age, gender, history of diabetes mellitus, nephropathy, length of time on dialysis, height, post-dialysis weight, habitual time and frequency of hemodialysis, and prescribed medications. Evaluation of daily urine output was based on oral questioning of the patients and was therefore semiquantitative: $\geq 500 \mathrm{~mL} / \mathrm{d}$ or $<500 \mathrm{~mL} / \mathrm{d}$. Dialysis parameters were recorded at the mid-week session, and biological analyses were all performed at the start of this hemodialysis session. Normalized protein nitrogen appearance (nPNA) was estimated from intradialytic changes in urea-nitrogen concentrations in the serum [1] and dialysis dose was estimated by a singlepool Kt/V (spKt/V), as recommended by Daugirdas et al. [12]. The ESRD adapted Charlson Comorbidity Index was performed for each patient [13].

Continuous 2-day dietary histories (that included a dialysis day and a non-dialysis day) were self-completed in a food diary, including oral nutritional supplements. Each food diary was then checked and/or corrected by an experienced dietician during a short interview with the patient. These data were then analyzed using Bilnut $7.5^{\circledR}$ software (Nutrisoft, France) to estimate DEI and DPI as well as weight-adjusted DEI and DPI which were measured as DEI and DPI divided by dry weight. Results provided are the mean values of the dialysis and the non dialysis day intakes. Bilnut $7.5^{\circledR}$ software is used to evaluate DEI and DPI from dietary histories. It is based on the French food composition databank named Ciqual which is published by the Observatory of Food Nutritional Quality, unit of ANSES (the French agency for food, environmental and occupational health safety). 
In the dialysis unit, predialysis serum albumin was assessed each week, as well as nutritional status based on BMI; nPNA was performed every three months. Patients with signs of malnutrition received nutritional counseling from trained nurses plus prescriptions for oral nutritional supplements. Patients with severe PEW symptoms were prescribed oral nutritional supplement (Fresubin 2kcal Drink ${ }^{\circledR}$, Fresenius contains $400 \mathrm{kcal}$ and $20 \mathrm{~g}$ of proteins in a 200mL bottle) during each dialysis session and/or intradialytic parenteral nutrition, as appropriate. Calorie and protein intakes of oral nutritional supplements were included in the DEI and DPI calculations. Base expenditure energy (BEE) was calculated according to the Harris and Benedict formula.

BIA was performed during the midweek hemodialysis session using Z-Hydra ${ }^{\circledR}$ (Bioparhom, France) which is a multifrequency bioimpedancemetry device that allows measurement during hemodialysis session. It provides data on lean mass and fat mass using specific algorithms developed by the manufacturer. Fluid compartments were not studied in this cohort. Normal values provided by the manufacturer were defined as mean \pm 1.96 standard deviations of values obtained in a healthy population of similar age and gender.

The Mann-Whitney, chi-squared, and Fisher's exact tests were performed to assess factors associated with diabetes mellitus. A linear-regression model was used to determine factors associated with DEI and DPI. In a first step, variables with a statistical $p$-value of $<0.10$ in the univariate analyses were considered eligible for inclusion in the multivariate analyses. In a second step, using a descending stepwise method, variables with a $p<0.05$ in the multivariate analyses were retained within the final model. Results are shown as their medians [IQRs] or percentages. Statistical analyses were performed with SPSS 15.0 software.

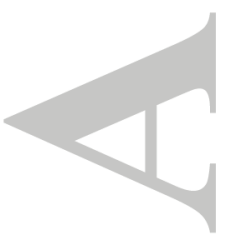




\section{Results}

\section{$\underline{\text { Studied population }}$}

A total of $87 \mathrm{HD}$ patients were included in this observational study. Median age [IQR] was 77.3 [71.1-84.8] years and 57.5\% of patients were male (Table 1). Of the total patients, 52.9\% had diabetes mellitus. All patients had end-stage renal failure and had been treated with conventional hemodialysis with high-flux membranes for 27.6 [13.0-70.1] months. Residual diuresis of $\geq 500 \mathrm{~mL}$ was present in $52.9 \%$ of patients.

The etiology for the primary cause of renal failure was diabetic nephropathy in $29.9 \%$ of patients, vascular nephropathy in $24.1 \%$, chronic interstitial nephritis in $8.0 \%$, non-diabetic glomerular disease in $4.6 \%$, autosomal dominant polycystic kidney disease in $2.3 \%$, other in $6.9 \%$, and unknown in $24.1 \%$.

Dialysis parameters are reported in Table 1. Most patients underwent at least $12 \mathrm{~h}$ of HD, distributed among three sessions per week. Median spKt/V [IQR] was 1.60 [1.47-1.81]. Vascular access was a native fistula in $67.8 \%$ of patients.

\section{$\underline{\text { Validity of the dietary-intake evaluation }}$}

To assess quality of DPI and DEI evaluation using continuous 2-day dietary histories, we compared weight-adjusted DPI, evaluated from dietary histories, to nPNA values (which are both indirect methods to assess protein intake). Weight-adjusted DPI and nPNA were statistically correlated $(p=0.04)$, which confirmed the quality of our continuous 2-day dietary history data (Figure 1). 


\section{$\underline{\text { Dietary intakes }}$}

There was very low dietary intakes in our aged and comorbid population, with a mean weight-adjusted DEI of 18.4 [15.7; 22.3] kcal/kg/day, which equals 1308 [1078; 1569] kcal/day (Table 2). This low estimated DEI was comparable to the median estimated BEE of 1311 [1180; 1509] kcal/day and was far below the recommended weight-adjusted DEI of 30$40 \mathrm{kcal} / \mathrm{kg} /$ day. Similarly, weight-adjusted DPI was low in most patients, with a mean weight-adjusted DPI of $0.80[0.66 ; 0.96] \mathrm{g} / \mathrm{kg} / \mathrm{day}$, which equals $57.5[47.1 ; 66.8] \mathrm{g} / \mathrm{day}$.

Daily intakes of most micronutrients were lower than advised in recommendations; among all the evaluated micronutrients, only phosphate intake was sufficient. Moreover, this low dietary intake was observed although $26.4 \%$ of the patients were also being prescribed oral nutritional supplements.

Energy intakes recorded on the dialysis day were similar to dietary intakes on non-dialysis day, but DPI and weight-adjusted DPI tended to be lower on the non-dialysis day (Table S1). Fewer patients had a weight-adjusted DPI below $1.1 \mathrm{~g} / \mathrm{kg} / \mathrm{day}$ on the non-dialysis day (70.0\%) compared to on the dialysis day $(89.7 \%)(p=0.003)$.

Within our population, 46 patients $(52.9 \%)$ had diabetes mellitus. When compared to patients without diabetes, patients with diabetes were younger $(p=0.01)$ and had a greater body weight $(p<0.0001)$ and BMI $(p<0.0001)$ (Tables 1 and 3). In univariate analyses, patients with diabetes had a lower weight-adjusted DEI and a lower weight-adjusted DPI than patients without, but total DEI and DPI did not differ between the two groups, which could be explained by the overall greater weight of patients with diabetes (Table 2). For other parameters, dietary intakes did slightly differ between the two groups: patients with diabetes ate less simple carbohydrates and more fibers, as recommended by dieticians in usual diabetic regimens. All other daily nutrient intakes were comparable between patients with diabetes 
and those without. Evaluated water intake was comparable, but not ultrafiltration volume, which was greater in patients with diabetes (Table 1).

\section{$\underline{\text { Nutritional status }}$}

Common nutritional and biological parameters of the population are reported in Table 3. Although our population was aged, nutritional parameters remained correct with a median [IQR] BMI of $26.5[23.0 ; 30.1] \mathrm{kg} / \mathrm{m}^{2}$, a median albumin of $39[36 ; 40] \mathrm{g} / \mathrm{L}$, and a median prealbumin of $0.28[0.22 ; 0.34] \mathrm{g} / \mathrm{L}$. These nutritional parameters were identical in patients with diabetes and those without.

Body composition analysis of our population showed that $36 \%$ of patients had an increased fat mass (as percentage of body weight) and $36 \%$ had a low lean mass. This observation was even worse for patients with diabetes where $46.3 \%$ of patients had a high fat mass (Table 3 ).

\section{Determinants of dietary intake}

Using uni- and multivariate analyses, we searched for parameters associated with DEI and DPI (Table 4) within: gender, age, diabetes, BMI, inflammation estimated with C-reactive protein (CRP), and the Charlson comorbidity index.

In the multivariate analysis, weight-adjusted DEI was statistically lower in patients with diabetes (coefficient $\left[\begin{array}{lllll}95 \% & \mathrm{CI}\end{array}-3.81[-5.21 ;-2.41] \mathrm{kcal} / \mathrm{kg} / \mathrm{day} ; p=0.01\right.$ ) but was not associated with the others parameters. When DEI was not adjusted for weight, diabetes was no longer associated with DEI, but female gender (-178 [-259; -961] kcal/day; $p=0.03)$ and a higher Charlson comorbidity index $(-30[-44 ;-15] ; 0.04)$ were associated with a lower calorie intake. Results for DPI were similar except that the Charlson comorbidity index did not reach significance: the DPI index for weight was statistically lower in patients with diabetes 
(coefficient [IQR] $-0.15[-0.21 ;-0.09] \mathrm{g} / \mathrm{kg} / \mathrm{day} ; p=0.01$ ) and DPI not indexed for weight was lower in female patients $(-7.6[-11.5 ;-3.8] \mathrm{g} / \mathrm{day} ; p=0.05)$.

\section{Determinants of serum albumin}

In the univariate analyses, a higher BMI, a higher nPNA, and lower values of CRP were associated with higher serum albumin (Table 5). A lower DEI indexed for body weight was associated with higher serum albumin, but this association disappeared when pooled with BMI and thus represents the effect of weight rather than DEI.

In the multivariate analyses, only a high BMI $(0.24[0.17 ; 0.31] ; p=0.001)$ and a low CRP (0.05 [-0.07; -0.03]; $p=0.002$ ) were associated with higher serum albumin (Table 5).

\section{Discussion}

In this observational cross-sectional study, we report on the dietary intake of 87 HD patients. In the multivariate analyses, female gender and a high Charlson comorbidity index score were associated with low calorie and protein intakes. Diabetes per se did not influence total daily nutritional intake, but as patients with diabetes are heavier patients without, weightadjusted DPI and DEI were lower in this subgroup of patients.

Continuous evaluation of 2-day dietary intake showed very low dietary intakes. One could suggest this was because of underestimating dietary intake in the questionnaires, but DPI correlated well with nPNA, which evaluates protein intake and so was unbiased by the patients' reporting (Figure 1).

We found a median DEI of $1308 \mathrm{kcal} /$ day (i.e., $18.4 \mathrm{kcal} / \mathrm{kg} /$ day) and a median DPI of 57.5 $\mathrm{g} /$ day (i.e., $0.80 \mathrm{~g} / \mathrm{kg} /$ day). These intakes are far below the recommended DEI and DPI values for HD patients of, respectively, 30-40 kcal/kg/day and $>1.1 \mathrm{~g} / \mathrm{kg} /$ day [1]. In fact, dietary intakes are below the recommended range for almost all nutrients, including fibers (Table 2). 
No study on HD patients has reported a DEI below $20 \mathrm{kcal} / \mathrm{kg} /$ day until now; most studies have reported intakes varying between 20 and $30 \mathrm{kcal} / \mathrm{kg} /$ day, which is still lower than the recommended values [6]. The very low intake might be explained by the old age and high comorbidity level of our population.

In our study, DEI was almost equivalent to BEE. HD patients might, however, have very low activity related energy expenditure $[14,15]$. In our aged HD population, physical activity might be considered as almost inexistent.

Interestingly, intakes are low, even of substances that accumulate during renal failure and that physicians and dieticians commonly recommend are avoided in their regimens. For example, our patients had very low sodium intakes: median of $1254 \mathrm{mg} / \mathrm{day}$ (i.e., $3187 \mathrm{mg} / \mathrm{day}$ of sodium chloride), but as sodium can be added separately after cooking, evaluation within the dietary diary could have been underestimated: thus, these data should be interpreted cautiously.

Phosphate intake, an accumulating compound during ESRD and associated with vascular calcification and mortality [16], was at the lower level of the recommended range. Phosphates are mostly found in protein. Although we have described a low protein intake in our patients, phosphate intake was within the normal range. Water intake, in contrast, was greater than the 500 to $750 \mathrm{~mL} / \mathrm{d}$ recommendation for anuric patients, leading to median ultrafiltration of $2000 \mathrm{~mL} / \mathrm{HD}$ session [1].

Nutritional parameters remained within normal ranges, with median albumin of $39 \mathrm{~g} / \mathrm{L}$ and a median BMI of $26.5 \mathrm{~kg} / \mathrm{m}^{2}$. However, BMI might not be a relevant parameter because $36 \%$ of our patients had high fat mass (in proportion to body weight) and $36 \%$ had low lean mass. Modification of body composition with an increase in fat mass and reduction of muscle mass is a well known feature of HD patients [17]. In a recent study, the ratio of serum creatinine to body-surface area has been included in nutritional scores and has been more efficient at 
predicting death than BMI [18]. Survival is more impacted by lean body mass than by fat mass in HD patients, and BMI should be adjusted with or replaced by a lean-mass biomarker, for example with plasmatic creatinine $[19,20]$. The low nutritional requirements in the highly inactive HD patient population could be an explanation of the maintenance of nutritional parameters in normal ranges $[14,15]$.

In multivariate analyses, the main determinants of dietary intake were gender and comorbidities, but not age or inflammation, which did not influence dietary intake in our study. Other studies have reported factors affecting dietary intakes. For example, secondary analysis of the HEMO study reported higher DEI and DPI in men, in younger patients, in patients without diabetes, and in patients with a high comorbidity score (measured with the Index of Co-Existing Disease (ICED) score) [21]. This study of 1901 patients included younger patients than ours, which could explain the influence of age on intake. However, we have confirmed the importance of female gender, comorbidities, and diabetes status, which negatively influenced dietary intake in our smaller study, thus pleading in favor of a major role for diabetes in lowering nutritional intake in HD patients. Interestingly, in the multivariate analyses of the HEMO study cohort, diabetes remained an important factor, but the comorbidity ICED score was no longer significant. Of note, diabetes is a component of the Charlson Comorbidity Index implying that diabetes is a central parameter that influences dietary intake in a negative way [22].

Weight-adjusted DEI and DPI were associated with diabetes, but not non-adjusted DEI and DPI (Table 4). This means patients with diabetes eat as much as patients without, but because they are heavier than patients without, they eat less per $\mathrm{kg}$ of weight. Fat mass was more frequently high in patients with diabetes than those without, and lean mass was low in $44.1 \%$ of patients with diabetes. Thus, even though patients with diabetes have a higher BMI, their nutritional status was no better than patients without and could even be worse. 
In our study, protein intake tended to be lower on the non-dialysis day. This finding is the opposite of that reported in the HEMO study, in which DEI and DPI were lowest on the dialysis day [21]. One explanation could be that PEW patients in our center have oral supplementation prescribed during the HD session.

Finally, water intake was similar in patients with or without diabetes, but ultrafiltration volume was statistically higher in the subgroup with diabetes, which might reflect unreported fluid intake in the diabetic population. Thirst favored by hyperglycemia could be responsible for this difference.

In the univariate analyses, BMI and nPNA were positively associated with serum albumin, whereas CRP was negatively correlated with serum albumin (Table 5). DEI indexed by body weight was also positively associated with serum albumin, but this association disappeared when it was pooled with BMI, and thus represents the effect of weight rather than DEI. In multivariate analyses, only BMI $(0.24[0.17 ; 0.31] ; p=0.001)$ and CRP $(-0.05[-0.07 ;-0.03]$; $p=0.002$ ) were independently associated with serum albumin (Table 5).

Appetite is a complex physiological process. Anorexia-induced inadequate nutrient intake is an important cause of malnutrition in HD patients, and a decline in protein and calorie intake becomes gradually manifest once glomerular-filtration rate declines to approximately $<25-38$ $\mathrm{mL} / \mathrm{min}$. [23]. The causes of anorexia in HD patients are multiple [24]: uremic toxins, a high pill burden, pain, medical treatments, and various comorbid conditions. Well-intended regimen prescriptions and advice on various dietary restrictions may also induce an unintended decrease in nutrient intake [7]. Restrictive diet recommendations, which are commonly provided to renal-failure patients (low phosphate, low potassium, low sodium, sugar free), could lead to even lower dietary intakes in patients who hardly cover their BEE [8]. Thus, the dietary intake should be individually evaluated prior to prescribing a diet in dialysis patients, especially in patients with diabetes, and intakes should be encouraged 
instead of being limited when DEI or DPI is low. However, fluid intake should be maintained at a low level to avoid volume overload and pulmonary edema.

Because nutrient intakes are low, we recommend that specialized dietary advice should be preferred to restrictive regimens in HD patients with diabetes.

Our study suffers from several limitations. Firstly, evaluation of dietary intake using food diaries might have underestimated oral intake [6] and the Bilnut $7.5^{\circledR}$ software could be imprecise. We believe though that even if oral intakes were underestimated by $20 \%$, most of our hemodialysis population still had far below the recommended intakes. To note, DPI were statistically correlated to nPNA evaluation, which favors correct evaluation. Our study might also be underpowered because only 87 patients were included. Another limitation could be that patients in our population were old and that our findings might not be extrapolated to younger patients. Nevertheless, DEI, DPI, weight-adjusted DEI and weight-adjusted DPI were not statistically different between patients $<$ or $\geq 75$ years-old (data not shown). Thus, age influenced less dietary intakes than comorbidities in our study.

In conclusion, we confirm that diabetes is an important factor associated with low dietary intake in HD patients, particularly in patients with several comorbidities. The dietary intake should be individually evaluated prior to prescribing a restrictive regimen in dialysis patients, especially in patients with diabetes.

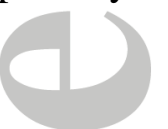

\section{Acknowledgements}

We thank Elisa Carreno and Nathalie Pedinielli, clinical research assistants, for their help in collecting the data. We thank Catherine Clement and Laure Justiniany, dieticians, for the dietary analyses. We thank Michel Cardot (Meditor SA) and Eva Ribbe (Bioparhom SA) for helping us compute and analyze the BIA data. 


\section{References}

1. Fouque D, Vennegoor M, ter Wee P, et al. EBPG guideline on nutrition. Nephrol Dial Transplant. 2007 May;22 Suppl 2: ii45-87.

2. Johansson L, Hickson M, Brown EA. Influence of psychosocial factors on the energy and protein intake of older people on dialysis. J Ren Nutr. 2013 Sep;23(5):348-355.

3. Fouque D, Kalantar-Zadeh K, Kopple J, et al. A proposed nomenclature and diagnostic criteria for protein-energy wasting in acute and chronic kidney disease. Kidney Int. 2008 Feb;73(4): 391-398.

4. Lim VS, Ikizler TA, Raj DS, Flanigan MJ. Does hemodialysis increase protein breakdown? Dissociation between whole-body amino acid turnover and regional muscle kinetics. $J A m$ Soc Nephrol. 2005 Apr;16(4):862-868.

5. Kalantar-Zadeh K, Ikizler TA, Block G, Avram MM, Kopple JD. Malnutrition-inflammation complex syndrome in dialysis patients: causes and consequences. Am J Kidney Dis. 2003 Nov;42(5):864-881.

6. Therrien M, Byham-Gray L, Beto J. A Review of Dietary Intake Studies in Maintenance Dialysis Patients. J Ren Nutr. 2015 Jul;25(4):329-338.

7. Kovesdy CP, Shinaberger CS, Kalantar-Zadeh K. Epidemiology of dietary nutrient intake in ESRD. Semin Dial. 2010 Jul-Aug;23(4):353-358.

8. Ikizler TA, Cano NJ, Franch $\mathrm{H}$, et al; International Society of Renal Nutrition and Metabolism. Prevention and treatment of protein energy wasting in chronic kidney disease patients: a consensus statement by the International Society of Renal Nutrition and Metabolism. Kidney Int. 2013 Dec;84(6):1096-1107.

9. Rabin BA, Boehmer TK, Brownson RC. Cross-national comparison of environmental and policy correlates of obesity in Europe. Eur J Public Health. 2007 Feb;17(1):53-61. 
10. van de Luijtgaarden MW, Jager KJ, Segelmark M, et al. Trends in dialysis modality choice and related patient survival in the ERA-EDTA Registry over a 20-year period. Nephrol Dial Transplant. 2016 Jan;31(1):120-8.

11. Bataille S, Landrier JF, Astier J, et al. The "Dose-Effect" Relationship Between 25Hydroxyvitamin D and Muscle Strength in Hemodialysis Patients Favors a Normal Threshold of $30 \mathrm{ng} / \mathrm{mL}$ for Plasma 25-Hydroxyvitamin D. J Ren Nutr. 2016 Jan;26(1):45-52.

12. Daugirdas JT. Second generation logarithmic estimates of single-pool variable volume Kt/V: an analysis of error. J Am Soc Nephrol. 1993;4:1205-1213.

13. Hemmelgarn BR, Manns BJ, Quan H, Ghali WA. Adapting the Charlson Comorbidity Index for use in patients with ESRD. Am J Kidney Dis. 2003 Jul;42(1):125-132.

14. Baria F1, Kamimura MA, Avesani CM, et al. Activity-related energy expenditure of patients undergoing hemodialysis. J Ren Nutr. 2011 May;21(3):226-234.

15. Panaye M, Kolko-Labadens A, Lasseur C, et al. Phenotypes influencing low physical activity in maintenance dialysis. J Ren Nutr. 2015 Jan;25(1):31-39.

16. Block GA, Klassen PS, Lazarus JM, Ofsthun N, Lowrie EG, Chertow GM. Mineral metabolism, mortality, and morbidity in maintenance hemodialysis. J Am Soc Nephrol. 2004 Aug;15(8):2208-2218.

17. Marcelli D, Brand K, Ponce P, et al. Longitudinal Changes in Body Composition in Patients After Initiation of Hemodialysis Therapy: Results From an International Cohort. J Ren Nutr. 2016 Mar;26(2):72-80.

18. Moreau-Gaudry X, Jean G, Genet L, et al. A simple protein-energy wasting score predicts survival in maintenance hemodialysis patients. J Ren Nutr. 2014 Nov;24(6):395-400.

19. Beddhu S, Pappas LM, Ramkumar N, Samore M. Effects of body size and body composition on survival in hemodialysis patients. J Am Soc Nephrol. 2003 Sep;14(9):2366-2372. 
20. Moreau-Gaudry X, Guebre-Egziabher F, Jean G, et al. Serum creatinine improves body mass index survival prediction in hemodialysis patients: a 1-year prospective cohort analysis from the ARNOS study. J Ren Nutr. 2011 Sep;21(5):369-375.

21. Burrowes JD, Larive B, Cockram DB, et al; Hemodialysis (HEMO) Study Group. Effects of dietary intake, appetite, and eating habits on dialysis and non-dialysis treatment days in hemodialysis patients: cross-sectional results from the HEMO study. J Ren Nutr. 2003 Jul;13(3):191-198.

22. Miskulin DC, Athienites NV, Yan G, et al; Hemodialysis (HEMO) Study Group. Comorbidity assessment using the Index of Coexistent Diseases in a multicenter clinical trial. Kidney Int. 2001 Oct;60(4):1498-1510.

23. Kopple JD, Berg R, Houser H, Steinman TI, Teschan P. Nutritional status of patients with different levels of chronic renal insufficiency. Modification of Diet in Renal Disease (MDRD) Study Group. Kidney Int Suppl 1989 Nov;27:S184-S194.

24. Bergstrom J. Mechanisms of uremic suppression of appetite. J Ren Nutr. 1999 Jul;9(3):129132.

25. Schlienger JL. Besoins nutritionnels et apports conseilles : adultes, femmes enceintes, personnes âgées, sportifs. In: Elsevier Masson Eds: Nutrition Clinique Pratique. Partie I. Nutrition générale et appliquée. Issy-les-Moulineaux; 2011, pp 43-56.

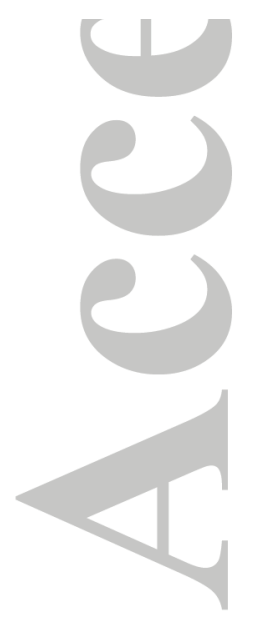


$p=0.04$

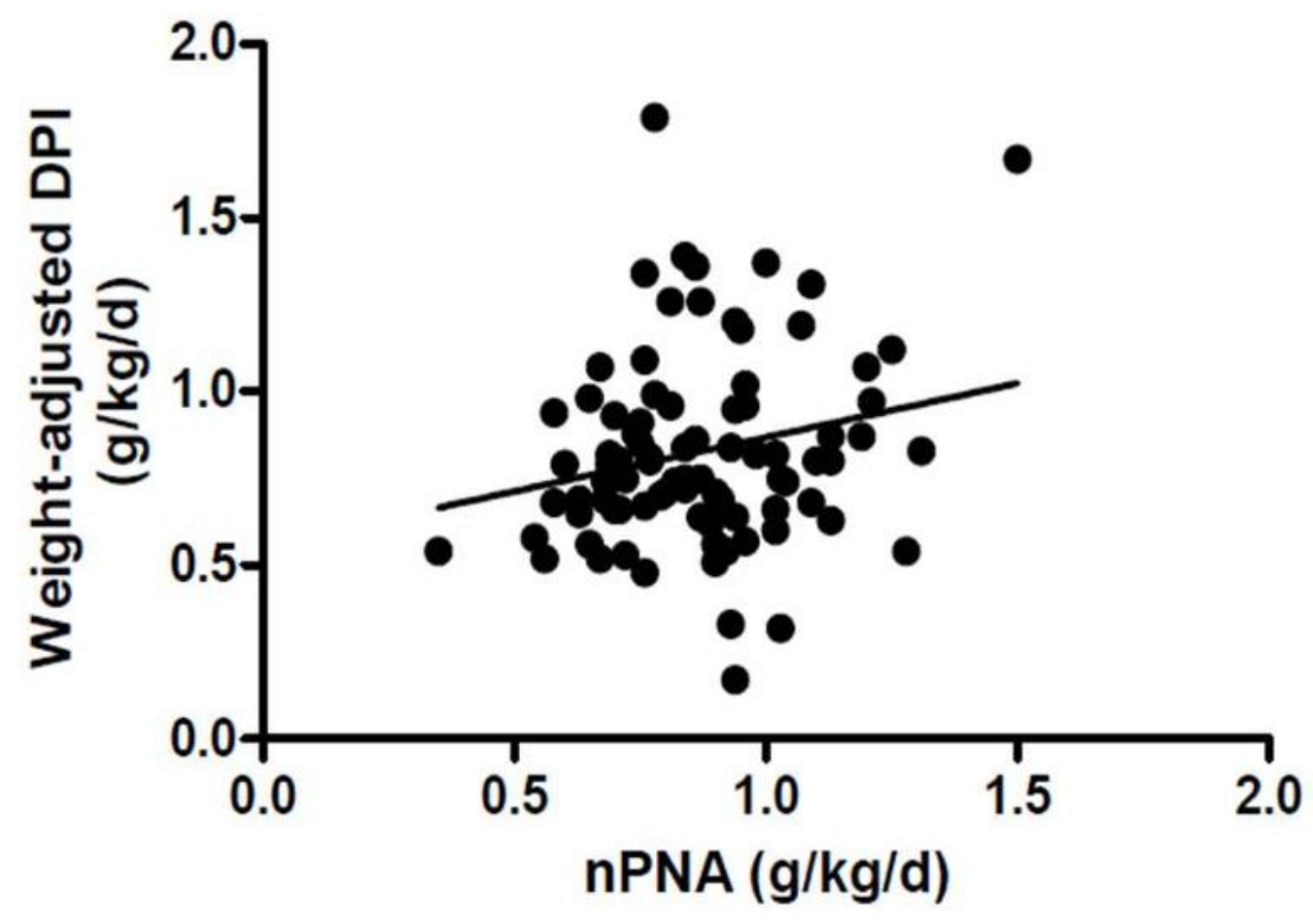

Figure 1: Weight-adjusted dietary protein intake (DPI) of a hemodialysis population associated with nPNA: univariate analyses (linear regression model, $n=87$ patients). nPNA: Normalized protein nitrogen appearance estimated from intradialytic changes in ureanitrogen concentrations in the serum [1]. 
Table 1: Demographic and HD parameters of a HD population according to diabetes ( $n=87$ patients). DM: Diabetes mellitus. ADPKD: Autosomal dominant polycystic kidney disease.

\begin{tabular}{|c|c|c|c|c|}
\hline & $\begin{array}{c}\text { Total } \\
\text { population } \\
(n=87)\end{array}$ & $\begin{array}{c}\text { Patients without } \\
\text { DM } \\
(n=41)\end{array}$ & $\begin{array}{c}\text { Patients with } \\
\text { DM } \\
(n=46)\end{array}$ & $\begin{array}{c}p- \\
\text { value }\end{array}$ \\
\hline & $\begin{array}{l}\text { Median[25-75] } \\
\text { or } \%\end{array}$ & $\begin{array}{c}\text { Median[25-75] } \\
\text { or } \%\end{array}$ & $\begin{array}{c}\text { Median[25-75] } \\
\text { or \% }\end{array}$ & \\
\hline Age (years) & 77.3 [71.1-84.8] & $82.9[71.4-87.6]$ & $75.4[70.7-81.1]$ & 0.01 \\
\hline Male gender & $57.5 \%$ & $61.0 \%$ & $54.3 \%$ & 0.53 \\
\hline $\begin{array}{l}\text { Time on dialysis } \\
\text { (months) }\end{array}$ & $27.6[13.0-70.1]$ & $31.8[12.7-101.4]$ & $26.6[12.9-51.8]$ & 0.21 \\
\hline $\begin{array}{r}\text { Primary cause of renal } \\
\text { failure } \\
\text { Diabetes } \\
\text { Vascular } \\
\text { Chronic interstitial } \\
\text { nephritis } \\
\text { Glomerular } \\
\text { ADPKD } \\
\text { Other } \\
\text { Unknown }\end{array}$ & $\begin{array}{c}29.9 \% \\
24.1 \% \\
8.0 \% \\
4.6 \% \\
2.3 \% \\
6.9 \% \\
24.1 \%\end{array}$ & $\begin{array}{c}0 \% \\
36.6 \% \\
12.2 \% \\
2.4 \% \\
2.4 \% \\
12.2 \% \\
34.1 \%\end{array}$ & $\begin{array}{c}56.5 \% \\
13.0 \% \\
4.3 \% \\
6.5 \% \\
2.2 \% \\
2.2 \% \\
15.2 \%\end{array}$ & - \\
\hline $\begin{array}{l}\text { Charlson comorbidity } \\
\text { index }\end{array}$ & 7 [5-9] & $6[4.5-7.5]$ & 7 [5-9] & 0.06 \\
\hline Diuresis $\geq 500 \mathrm{~mL} / \mathrm{d}$ & $52.9 \%$ & $56.1 \%$ & $50.0 \%$ & 0.57 \\
\hline $\begin{array}{l}\text { Weekly hemodialysis } \\
\text { time } \\
\qquad 12 \mathrm{~h} / \mathrm{w} \\
\geq 12 \mathrm{~h} / \mathrm{w}\end{array}$ & $\begin{array}{c}3.4 \% \\
96.6 \%\end{array}$ & $\begin{array}{c}4.9 \% \\
95.1 \%\end{array}$ & $\begin{array}{c}2.2 \% \\
97.8 \%\end{array}$ & 0.60 \\
\hline $\begin{array}{l}\text { Weekly hemodialysis } \\
\text { frequency } \\
\qquad \begin{array}{r}3 \text { sessions/w } \\
>3 \text { sessions/w }\end{array}\end{array}$ & $\begin{array}{l}95.4 \% \\
4.6 \%\end{array}$ & $\begin{array}{l}97.6 \% \\
2.4 \%\end{array}$ & $\begin{array}{c}93.5 \% \\
6.5 \%\end{array}$ & 0.62 \\
\hline $\begin{array}{l}\text { Vascular access } \\
\text { Native fistula } \\
\text { Gore-Tex } \\
\text { Catheter }\end{array}$ & $\begin{array}{l}67.8 \% \\
14.9 \% \\
17.2 \% \\
\end{array}$ & $\begin{array}{l}70.7 \% \\
17.1 \% \\
12.2 \% \\
\end{array}$ & $\begin{array}{l}65.2 \% \\
13.0 \% \\
21.7 \% \\
\end{array}$ & 0.48 \\
\hline spKt/V (Daugirdas) & $1.60[1.47-1.81]$ & $1.60[1.48-1.91]$ & $1.60[1.44-1.77]$ & 0.39 \\
\hline $\begin{array}{l}\text { Ultrafiltration volume } \\
\text { (mL) }\end{array}$ & $\begin{array}{c}2000[1500- \\
2800]\end{array}$ & $\begin{array}{c}1705[1300- \\
2250] \\
\end{array}$ & $\begin{array}{c}2400[1703- \\
3000]\end{array}$ & 0.001 \\
\hline
\end{tabular}

DM: Diabetes mellitus. ADPKD: Autosomal dominant polycystic kidney disease. 
Table 2: Dietary intake evaluated by continuous 2-day dietary histories according to diabetes ( $n=87$ patients). DM: Diabetes mellitus. BEE: base energy expenditure. DEI: daily energy intake. DPI: daily protein intake. *Recommended daily intakes are provided for HD patients according to European Best Practice Guidelines Guideline on Nutrition [1] or from elderly populations when no HD patient-specific recommended values were available [25].

\begin{tabular}{|c|c|c|c|c|c|}
\hline & $\begin{array}{l}\text { Daily recommended } \\
\text { intake in the elderly } \\
\text { (*or in HD patients) }\end{array}$ & $\begin{array}{c}\text { Total population } \\
\qquad(n=87)\end{array}$ & $\begin{array}{l}\text { Patients without DM } \\
\qquad(n=41)\end{array}$ & $\begin{array}{l}\text { Patients with DM } \\
\quad(n=46)\end{array}$ & $p$-value \\
\hline & & Median[25-75] or $\%$ & Median[25-75] or $\%$ & Median[25-75] or \% & \\
\hline BEE (kcal/day) & - & 1311 [1180-1509] & 1249 [1038-1379] & 1407 [1252-1612] & 0.001 \\
\hline Weight adjusted DEI (kcal/kg/day) & $30-40 *$ & $18.4[15.7-22.3]$ & $20.2[17.2-24.9]$ & $16.9[13.8-21.0]$ & 0.01 \\
\hline DEI (kcal/day) & - & 1308 [1078-1569] & $1292[1054-1614]$ & 1309 [1080-1534] & 0.92 \\
\hline Weight adjusted DPI (g/kg/day) & $>1.1^{*}$ & $0.80[0.66-0.96]$ & $0.84[0.69-1.08]$ & $0.75[0.63-0.89]$ & 0.04 \\
\hline DPI (g/day) & - & $57.5[47.1-66.8]$ & $55.2[42.7-65.1]$ & $57.7[48.7-67.0]$ & 0.48 \\
\hline Lipids (g/day) & - & $54.4[45.9-66.9]$ & $56.1[45.4-64.9]$ & $50.8[45.1-72.3]$ & 0.97 \\
\hline Simple carbohydrates (g/day) & - & $49.9[38.7-69.1]$ & $55.3[43.4-77.6]$ & $47.3[33.5-56.7]$ & 0.01 \\
\hline Total carbohydrates (g/day) & - & $137[116-168]$ & $138[115-177]$ & $137[116-161]$ & 0.75 \\
\hline Fiber (g/day) & - & $11.5[9.0-14.4]$ & $10.3[7.8-13.3]$ & $12.5[9.9-15.6]$ & 0.03 \\
\hline Water (mL/day) & - & $1116[1018-1418]$ & 1116 [967-1515] & 1113 [1021-1373] & 0.90 \\
\hline Sodium (mg/day) & $2000-2300 *$ & $1254[920-1678]$ & $1252[917-1632]$ & $1256[917-1753]$ & 0.88 \\
\hline Potassium (mg/day) & $\begin{array}{c}1950-2730 \text { if } \\
\mathrm{K}+>6 \mathrm{mmol} / \mathrm{L}^{*}\end{array}$ & 1949 [1602-2205] & $1715[1477-2234]$ & 2003 [1728-2202] & 0.19 \\
\hline Calcium (mg/day) & $<2000^{*}$ & $523[388-714]$ & $553[479-757]$ & 475 [307-619] & 0.04 \\
\hline Phosphate (mg/day) & $800-1000^{*}$ & 830 [694-967] & 854 [717-998] & 806 [683-957] & 0.31 \\
\hline Magnesium (mg/day) & $\geq 400$ & $163[131-202]$ & $168[129-204]$ & $160[137-201]$ & 1.0 \\
\hline Iron (mg/day) & $\geq 10$ & $7.1[5.8-8.6]$ & $6.4[5.4-8.1]$ & $7.2[6.3-9.2]$ & 0.14 \\
\hline Carotene $(\mu \mathrm{g} /$ day $)$ & - & 1390 [604-3383] & $1195[500-2358]$ & $1470[675-4071]$ & 0.19 \\
\hline Retinol - vitamin A ( $\mu \mathrm{g} /$ day $)$ & $700-800^{*}$ & $232[147-384]$ & $282[176-401]$ & $199[137-359]$ & 0.09 \\
\hline Thiamin - vitamin B1 (mg/day) & $\geq 1.2$ & $0.70[0.54-0.95]$ & $0.75[0.58-0.96]$ & $0.69[0.53-0.95]$ & 0.52 \\
\hline Riboflavin - vitamin B2 (mg/day) & $\geq 1.6$ & $0.95[0.73-1.34]$ & $0.97[0.72-1.17]$ & $0.94[0.70-1.22]$ & 0.34 \\
\hline Niacin - vitamin PP/B3 (mg/day) & $\geq 14$ & $10.0[7.0-13.5]$ & $9.0[7.0-13.8]$ & $10.8[8.0-13.6]$ & 0.21 \\
\hline Pantothenic acid - vitamin B5 (mg/day) & - & $2.6[2.2-3.3]$ & $2.7[2.2-3.2]$ & $2.6[2.1-3.3]$ & 0.89 \\
\hline
\end{tabular}




\begin{tabular}{|c|c|c|c|c|c|}
\hline Pyridoxine - vitamin B6 (mg/day) & $\geq 2.2$ & $0.92[0.75-1.17]$ & $0.89[0.72-1.17]$ & $0.95[0.77-1.18]$ & 0.58 \\
\hline Folate - vitamin B9 ( $\mu$ g/day $)$ & $\geq 350$ & $174[130-231]$ & $180[115-225]$ & $172[131-240]$ & 0.85 \\
\hline Cobalamin - vitamin B12 ( $\mu \mathrm{g} /$ day $)$ & $\geq 3.0$ & $2.37[1.23-3.84]$ & $2.37[1.17-3.23]$ & $2.32[1.37-4.14]$ & 0.52 \\
\hline Vitamin C (mg/day) & $\geq 120$ & $50.0[27.5-84.5]$ & $47.0[26.0-81.5]$ & $52.0[31.0-94.8]$ & 0.43 \\
\hline Cholecalciferol - vitamin D ( $\mu \mathrm{g} /$ day) & $\geq 10$ & $1.0[0.0-1.5]$ & $1.0[0.3-1.5]$ & $0.5[0.0-2.0]$ & 0.49 \\
\hline Tocopherol - vitamin E (mg/day) & $20-50$ & $6.0[3.5-10.0]$ & $5.5[3.5-9.5]$ & $6.5[4.0-10.1]$ & 0.40 \\
\hline Oral nutritional supplement prescription & - & $26.4 \%$ & $31.7 \%$ & $21.7 \%$ & 0.29 \\
\hline
\end{tabular}

DM: Diabetes mellitus. BEE: base energy expenditure. DEI: daily energy intake. DPI: daily protein intake.

* Recommended daily intakes are provided for HD patients according to European Best Practice Guidelines Guideline on Nutrition [1] or from elderly populations when no HD patient-specific recommended values were available [24].

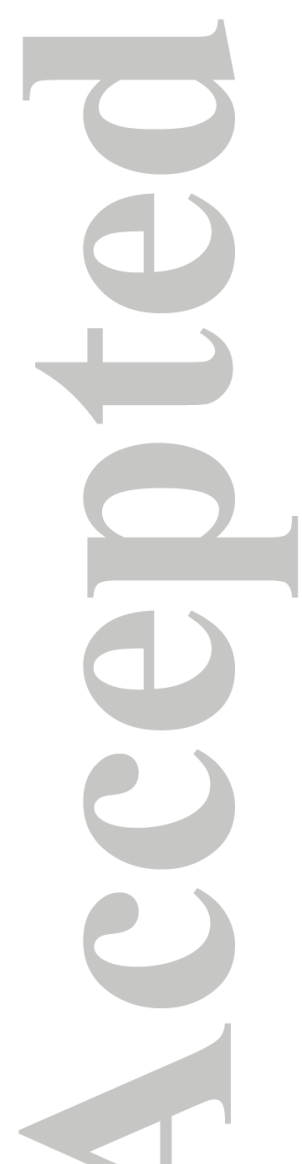


Table 3: Nutritional status according to diabetes ( $n=87$ patients). DM: Diabetes mellitus. HD: hemodialysis. BMI: body-mass index. nPNA: normalized protein nitrogen appearance. BIA: bioimpedancemetry analyses. * Recommended values for hemodialysis patients are provided according to European Best Practice Guidelines Guideline on Nutrition [1]. ${ }^{\S} p$ value is for Low+Normal vs. High. ${ }^{\varphi} p$-value is for Low $v s$. Normal+High.

\begin{tabular}{|c|c|c|c|c|c|}
\hline & $\begin{array}{c}\text { Laboratory } \\
\text { normal ranges } \\
(* \text { or } \\
\text { recommended } \\
\text { value in } \mathrm{HD} \\
\text { patients) }\end{array}$ & $\begin{array}{c}\text { Total } \\
\text { population } \\
(n=87)\end{array}$ & $\begin{array}{c}\text { Patients } \\
\text { without DM } \\
\quad(n=41)\end{array}$ & $\begin{array}{c}\text { Patients } \\
\text { with DM } \\
(n=46)\end{array}$ & $\begin{array}{c}p- \\
\text { value }\end{array}$ \\
\hline 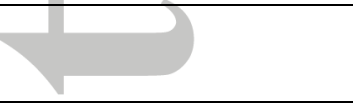 & & $\begin{array}{c}\text { Median[25- } \\
75] \text { or } \%\end{array}$ & $\begin{array}{c}\text { Median[25- } \\
75] \text { or } \%\end{array}$ & $\begin{array}{c}\text { Median[25- } \\
75] \text { or } \%\end{array}$ & \\
\hline $\begin{array}{l}\text { Physical } \\
\text { examination } \\
\text { Weight }(\mathrm{kg}) \\
\text { BMI }\left(\mathrm{kg} / \mathrm{m}^{2}\right) \\
\text { Mid-upper-arm } \\
\text { circumference }(\mathrm{cm}) \\
\text { Mid-lower-limb } \\
\text { circumference }(\mathrm{cm}) \\
\text { Handgrip }(\mathrm{kg})\end{array}$ & $\begin{array}{c}- \\
-23.0 * \\
- \\
- \\
-\end{array}$ & $\begin{array}{c}71.9[59.9- \\
84.0] \\
26.5[23.0- \\
30.1] \\
27.5[24.0- \\
31.0] \\
31.5[28.0- \\
34.0] \\
14.1[10.5- \\
24.2]\end{array}$ & $\begin{array}{c}62.4[52.5- \\
73.5] \\
24.0[20.1- \\
26.3] \\
26.0[22.0- \\
28.0] \\
28.0[30.0- \\
33.0] \\
13.3[9.6- \\
25.9]\end{array}$ & $\begin{array}{c}77.0[65.9- \\
88.2] \\
29.1[26.4- \\
32.9] \\
30.0[27.0- \\
32.0] \\
32.0[30.0- \\
34.3] \\
14.3[11.0- \\
20.6]\end{array}$ & $\begin{array}{c}<10^{-3} \\
<10^{-3} \\
<10^{-3} \\
0.006 \\
0.82\end{array}$ \\
\hline $\begin{array}{l}\text { Serum albumin } \\
(\mathrm{g} / \mathrm{L}) \\
\text { Prealbumin }(\mathrm{g} / \mathrm{L}) \\
\text { Predialysis } \\
\text { creatinine }(\mu \mathrm{mol} / \mathrm{L}) \\
\text { Predialysis urea } \\
(\mathrm{mmol} / \mathrm{L}) \\
\text { nPNA } \\
\text { HbA1c (\%) } \\
\text { Potassium } \\
\text { (mmol/L) } \\
\text { Calcium (mmol/L) } \\
\text { Phosphate } \\
(\mathrm{mmol} / \mathrm{L}) \\
\text { C-reactive protein } \\
(\mathrm{mg} / \mathrm{L})\end{array}$ & $\begin{array}{c}>40^{*} \\
>0.3^{*} \\
- \\
- \\
>1.0^{*} \\
- \\
3.5-5.5 \\
2.18-2.6 \\
0.77-1.64 \\
<0.5\end{array}$ & $\begin{array}{c}39[36-40] \\
0.28[0.22- \\
0.34] \\
614[461- \\
775] \\
19.4[15.8- \\
22.6] \\
0.86[0.72- \\
0.99] \\
5.4[5.0-6.1] \\
5.1[4.6-5.5] \\
2.22[2.09- \\
2.35] \\
1.46[1.19- \\
1.66] \\
6.6[2.4- \\
13.3]\end{array}$ & $\begin{array}{c}38[34-40] \\
0.26[0.19- \\
0.34] \\
485[594- \\
800] \\
19.4[16.5- \\
22.0] \\
0.85[0.76- \\
0.96] \\
5.0[4.7-5.2] \\
5.1[4.6-5.6] \\
2.21[2.01- \\
2.36] \\
1.39[1.03- \\
1.60] \\
8.4[3.1-17.1]\end{array}$ & $\begin{array}{c}39[36.8-40] \\
0.30[0.25- \\
0.34] \\
629446-775 \\
19.214 .6- \\
23.8 \\
0.890 .71- \\
1.02 \\
6.1[5.5-6.6] \\
5.04 .6-5.4 \\
2.232 .13- \\
2.35 \\
1.551 .20- \\
1.70 \\
4.62 .1-12.7\end{array}$ & $\begin{array}{l}0.21 \\
0.11 \\
0.95 \\
0.84 \\
0.85 \\
<10^{-3} \\
0.55 \\
0.62 \\
0.21 \\
0.12\end{array}$ \\
\hline $\begin{array}{l}\text { Folate - vitamin } \\
\text { B9 }(\mathrm{ng} / \mathrm{mL})\end{array}$ & $>5.38$ & $\begin{array}{c}4.8[3.9- \\
18.7]\end{array}$ & 4.7 [3.7-28.4] & $4.83 .9-16.3$ & 0.76 \\
\hline $\begin{array}{l}\text { Cobalamin - } \\
\text { vitamin B12 } \\
(\mathrm{pg} / \mathrm{mL})\end{array}$ & $211-911$ & $\begin{array}{l}311[261- \\
458]\end{array}$ & $\begin{array}{l}298[251- \\
439]\end{array}$ & $347279-475$ & 0.08 \\
\hline $\begin{array}{l}\text { 25-hydroxyvitamin } \\
\text { D (ng/mL) }\end{array}$ & $\geq 30$ & $\begin{array}{c}32.9[23.2- \\
39.6]\end{array}$ & $\begin{array}{c}34.2[22.9- \\
41.2]\end{array}$ & $\begin{array}{l}31.124 .5- \\
38.1\end{array}$ & 0.43 \\
\hline Body composition & & & & & \\
\hline
\end{tabular}




\begin{tabular}{|r|c|c|c|c|c|}
\hline (BIA) & & & & $0.04^{\S}$ \\
Fat mass (\% & $2.5 \%$ & $0 \%$ & $0 \%$ & $0 \%$ & \\
of body weight) & $95 \%$ & $64.0 \%$ & $76.5 \%$ & $53.7 \%$ & \\
Low & $2.5 \%$ & $36.0 \%$ & $23.5 \%$ & $46.3 \%$ & \\
Normal & & & & & $0.18^{\varphi}$ \\
High & $2.5 \%$ & $36.0 \%$ & $29.3 \%$ & $44.1 \%$ & \\
Lean mass (\% & $95 \%$ & $60.0 \%$ & $65.9 \%$ & $52.9 \%$ & \\
of body weight) & $2.5 \%$ & $4.0 \%$ & $4.9 \%$ & $2.9 \%$ & \\
Low & & & & & \\
High & & & & & \\
\hline
\end{tabular}

DM: Diabetes mellitus. HD: hemodialysis. BMI: body-mass index. nPNA: normalized protein nitrogen appearance. BIA: bioimpedancemetry analyses.

* Recommended values for hemodialysis patients are provided according to European Best Practice Guidelines Guideline on Nutrition [1]

$\S p$-value is for Low+Normal vs. High. ${ }^{\varphi} p$-value is for Low vs. Normal+High.

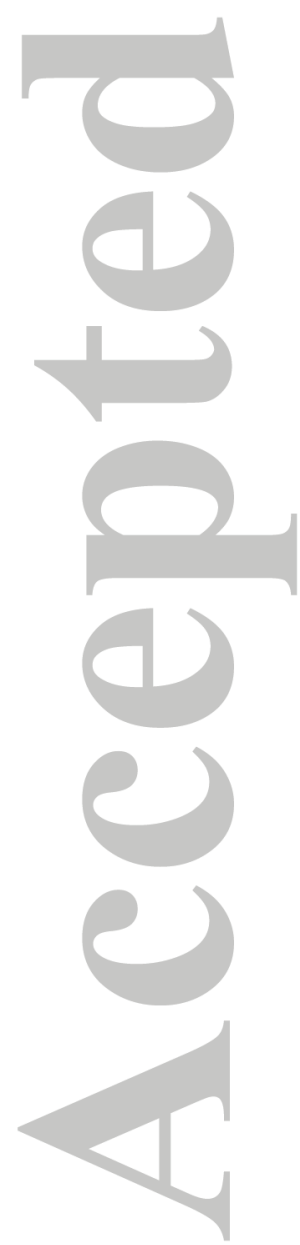


Table 4: Factors associated with daily nutritional intakes: univariate and multivariate analyses (linear regression models, $n=87$ patients). DEI: daily energy intake. DPI: daily protein intake. BMI: body-mass index. CRP: C-reactive protein. BMI was analyzed only for DEI; DPI was not indexed according to weight because DEI and DPI already included a morphologic parameter: weight.

\begin{tabular}{|c|c|c|c|c|c|}
\hline 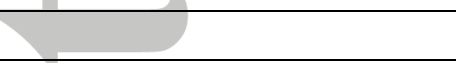 & & \multicolumn{2}{|c|}{ Monovariate analyses } & \multicolumn{2}{|c|}{ Multivariate analyses } \\
\hline Daily nutritional intakes & Factors & Coefficient [95\% CI] & $p$-value & $\begin{array}{c}\text { Adjusted } \\
\text { coefficient }[95 \% \mathrm{CI}]\end{array}$ & $p$-value \\
\hline $\begin{array}{l}\text { Weight-adjusted DEI } \\
\text { (kcal/kg/day) }\end{array}$ & $\begin{array}{l}\text { Female gender } \\
\text { Age (years) } \\
\text { Diabetes mellitus } \\
\text { CRP (mg/L) } \\
\text { Charlson comorbidity index }\end{array}$ & $\begin{array}{c}1.27[-0.20 ; 2.73] \\
0.02[-0.05 ; 0.08] \\
-3.81[-5.21 ;-2.41] \\
0.01[-0.01 ; 0.03] \\
-0.41[-0.67 ;-0.15]\end{array}$ & $\begin{array}{l}0.39 \\
0.77 \\
0.01 \\
0.46 \\
0.11\end{array}$ & $-3.81[-5.21 ;-2.41]$ & 0.01 \\
\hline DEI (kcal/day) & $\begin{array}{l}\text { Female gender } \\
\text { Age (years) } \\
\text { Diabetes mellitus } \\
\text { BMI }\left(\mathrm{kg} / \mathrm{m}^{2}\right) \\
\text { CRP }(\mathrm{mg} / \mathrm{L}) \\
\text { Charlson comorbidity index }\end{array}$ & $\begin{array}{c}-157[-239 ;-74] \\
-8[-11 ;-4] \\
7[-76 ; 91] \\
-4[-11 ; 4] \\
0.5[-0.4 ; 1.3] \\
-26[-40 ;-11]\end{array}$ & $\begin{array}{l}0.06 \\
0.04 \\
0.93 \\
0.61 \\
0.57 \\
0.08\end{array}$ & $-30[-44 ;-15]$ & 0.03 \\
\hline $\begin{array}{c}\text { Weight-adjusted DPI } \\
\text { (g/kg/day) }\end{array}$ & $\begin{array}{l}\text { Female gender } \\
\text { Age (years) } \\
\text { Diabetes mellitus } \\
\text { CRP (mg/L) } \\
\text { Charlson comorbidity index }\end{array}$ & $\begin{array}{c}0.01[-0.05 ; 0.07] \\
0.00[-0.01 ; 0.01] \\
-0.15[-0.21 ;-0.09] \\
0.00[-0.01 ; 0.01] \\
-0.01[-0.02 ; 0.00] \\
\end{array}$ & $\begin{array}{l}0.84 \\
0.53 \\
0.01 \\
0.62 \\
0.32 \\
\end{array}$ & $-0.15[-0.21 ;-0.09]$ & 0.01 \\
\hline DPI (g/day) & $\begin{array}{l}\text { Female gender } \\
\text { Age (years) } \\
\text { Diabetes mellitus } \\
\text { BMI }\left(\mathrm{kg} / \mathrm{m}^{2}\right) \\
\text { CRP }(\mathrm{mg} / \mathrm{L}) \\
\text { Charlson comorbidity index }\end{array}$ & $\begin{array}{c}-7.6[-11.5 ;-3.8] \\
-0.2[-0.4 ;-0.1] \\
1.2[-2.6 ; 5.1] \\
0.2[-0.1 ; 0.6] \\
0.0[-0.1 ; 0.1] \\
-0.6[-1.3 ;-0.01]\end{array}$ & $\begin{array}{l}0.05 \\
0.18 \\
0.75 \\
0.53 \\
0.72 \\
0.38\end{array}$ & $-7.6[-11.5 ;-3.8]$ & 0.05 \\
\hline
\end{tabular}

DEI: daily energy intake. DPI: daily protein intake. BMI: body-mass index. CRP: C-reactive protein.

BMI was analyzed only for DEI; DPI was not indexed according to weight because DEI and DPI already included a morphologic parameter: weight. 
Table 5: Factors associated with serum albumin (g/L): univariate and multivariate analyses (linear regression model, $n=87$ patients). BMI: body-mass index. DEI: daily energy intake. DPI: daily protein intake. nPNA: normalized protein nitrogen appearance.

\begin{tabular}{|l|c|c|}
\hline & Coefficient [95\% CI] & $p$-value \\
\hline Monovariate analyses & & \\
\hline Age (years) & $-0.02[-0.06 ; 0.02]$ & 0.57 \\
Female gender & $-0.86[-1.77 ; 0.06]$ & 0.35 \\
Diabetes mellitus & $1.69[0.18 ; 2.58]$ & 0.06 \\
BMI (kg/m²) & $0.29[0.21 ; 0.36]$ & $<10^{-3}$ \\
Weight-adjusted DEI (kcal/kg/day) & $-0.15[-0.21 ;-0.08]$ & 0.03 \\
DEI (kcal/day) & $0.001[0.00 ; 0.002]$ & 0.48 \\
Weight-adjusted DPI (kg/day) & $-1.79[-3.40 ;-0.17]$ & 0.27 \\
DPI (g/day) & $0.04[0.01 ; 0.06]$ & 0.13 \\
nPNA (g/day) & $4.26[2.05 ; 6.47]$ & 0.06 \\
C-reactive protein (mg/L) & $-0.03[-0.04 ;-0.02]$ & $<10^{-3}$ \\
\hline Multivariate analyses & & \\
\hline BMI (kg/m²) & $0.24[0.17 ; 0.31]$ & 0.001 \\
C-reactive protein (mg/L) & $-0.05[-0.07 ;-0.03]$ & 0.002 \\
\hline
\end{tabular}

BMI: body-mass index. DEI: daily energy intake. DPI: daily protein intake. nPNA:

normalized protein nitrogen appearance.

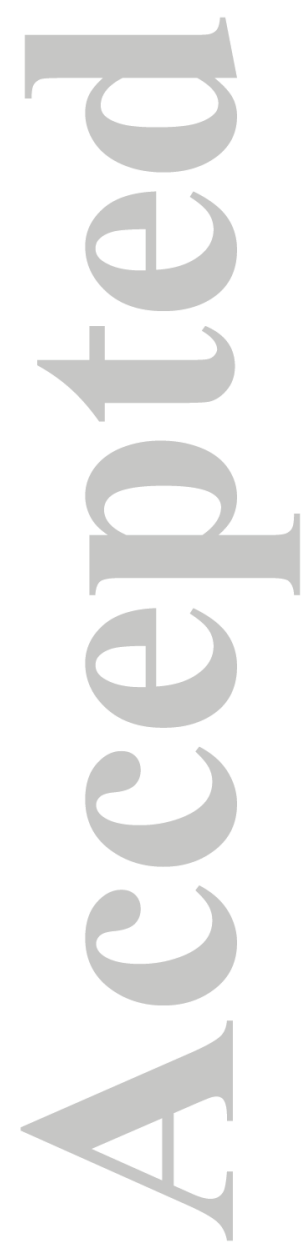

